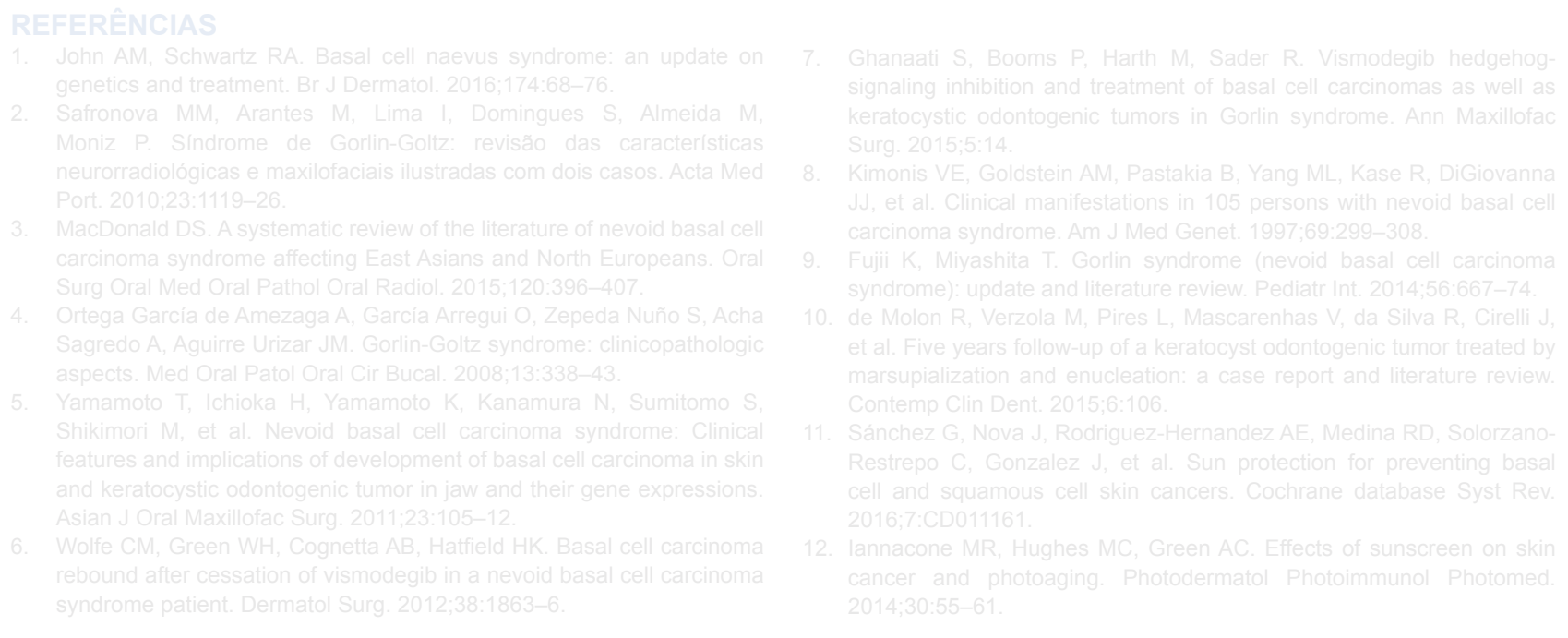

\title{
Carcinoid Syndrome and Carcinoid Heart Disease as Manifestations of Non-Metastatic Ovarian Neuroendocrine Tumour
}

\section{Síndrome Carcinoide e Doença Carcinoide Cardíaca como Manifestações de Tumor Neuroendócrino do Ovário Não Metastático}

Joana SIMÕES-PEREIRA ${ }^{1}$, Lai Mun WANG ${ }^{2}$, Attila KARDOS ${ }^{3}$, Ashley GROSSMAN ${ }^{4}$

Acta Med Port 2017 May;30(5):421-425 - https://doi.org/10.20344/amp.7713

\section{ABSTRACT}

The carcinoid syndrome is rare but it is associated with carcinoid heart disease in more than a half of the cases. Carcinoid heart disease is typically characterised by morphological and functional modifications of right-sided valves. Its aetiology is probable multifactorial but serotonin appears to play a key role in the development of this valvular disease. Unlike gastrointestinal neuroendocrine tumours, ovarian neuroendocrine tumours can present with carcinoid syndrome and carcinoid heart disease in the absence of liver metastases; such ovarian neuroendocrine tumours are a unique clinical entity. The additional burden of cardiac impairment in these patients represents a significant reduction in survival. Early recognition and surgical valve replacement before advanced heart failure is established may improve the clinical outcome. We report the case of a woman with an ovarian neuroendocrine tumour and highly symptomatic carcinoid heart disease who was submitted to tumour resection followed by valvuloplasty. She demonstrated an outstanding clinical improvement and has remained free of tumour and symptomatology.

Keywords: Carcinoma, Neuroendocrine; Carcinoid Heart Disease; Carcinoid Tumor; Ovarian Neoplasms

\section{RESUMO}

A síndrome carcinoide é rara mas encontra-se associada, em cerca de metade dos casos, a doença carcinoide cardíaca. Esta patologia cardíaca caracteriza-se tipicamente por alterações morfo-funcionais das válvulas direitas. A sua etiologia é provavelmente multifatorial mas, aparentemente, a serotonina parece exercer um papel preponderante no desenvolvimento desta doença valvular. Ao contrário dos tumores neuroendócrinos gastrointestinais, os tumores neuroendócrinos do ovário podem apresentar síndrome carcinoide e doença carcinoide cardíaca na ausência de metastização hepática, tornando os tumores neuroendócrinos do ovário uma entidade clínica única. Estas alterações cardíacas acarretam uma diminuição adicional da sobrevivência destes doentes. Portanto, o reconhecimento precoce desta entidade e a substituição valvular prévia ao estabelecimento da insuficiência cardíaca avançada podem melhorar a evolução clínica destes doentes. Os autores apresentam o caso de uma mulher com tumor neuroendócrino do ovário e doença carcinoide cardíaca muito sintomática que foi submetida a resseção tumoral seguida de valvuloplastia. A doente demonstrou uma marcada melhoria clínica e tem permanecido livre de doença e assintomática.

Palavras-chave: Carcinoma Neuroendócrino; Doença Carcinoide Cardíaca; Neoplasias do Ovário; Tumor Carcinoide

1. Serviço de Endocrinologia. Instituto Português de Oncologia de Lisboa Francisco Gentil. Lisboa. Portugal.

2. Department of Pathology. John Radcliffe Hospital. Oxford. United Kingdom.

3. Department of Cardiology. Milton Keynes Hospital. Buckinghamshire. United Kingdom.

4. Oxford Centre for Diabetes, Endocrinology and Metabolism. Churchill Hospital. Oxford. United Kingdom.

$\triangle$ Autor correspondente: Joana Simões-Pereira. joanasimoespereira@gmail.com

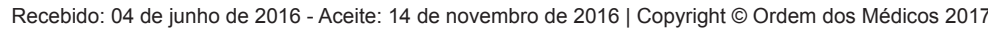




\section{INTRODUCTION}

Neuroendocrine tumours (NETs) of the mid-gut, often referred to as 'carcinoid tumours', are associated in up to $30 \%-40 \%$ of cases with a constellation of symptoms flushing, diarrhoea, bronchoconstriction and hypotension - generally called the carcinoid syndrome (CS). ${ }^{1}$ Carcinoid heart disease $(\mathrm{CHD})$ may be the initial manifestation of the disease and more than $50 \%$ of all patients with CS will evidence right-sided valve involvement. ${ }^{2}$ The 3 -year mortality rate for patients with carcinoid heart disease is $31 \%$, whereas carcinoid patients without CHD have approximately twice the survival rate. ${ }^{3}$ Many of the manifestations of the CS are due to the secretion of $5 \mathrm{HT}$ (serotonin), which is usually inactivated after transfer by the portal vein to the liver. Thus, the CS is almost always associated with the presence of multiple liver metastases or, rarely, with extensive peritoneal seeding by-passing hepatic inactivation. However, we present a case of an ovarian carcinoid which presented symptomatic cardiac valvular disease in the absence of hepatic metastases due to the direct venous drainage into the ovarian vein and systemic circulation.

\section{CASE REPORT}

A 54-year-old woman, submitted to bariatric surgery (Roux-en-Y bypass) and cholecystectomy more than five years ago, in another institution, was referred due to bilateral leg oedema, unresponsive to furosemide, and a $10 \mathrm{~cm}$ pelvic mass found on an abdominal ultrasound. She also complained of lower abdominal pain, diarrhoea and flushing, mainly after eating, and mild shortness of breath. The gastrointestinal symptoms and flushing were initially attributed to her previous bariatric surgery. Physical examination did not evidence any cutaneous lesions or cyanosis; chest examination was normal and cardiac auscultation evidenced a systolic murmur in the tricuspid area. Abdominal examination revealed an enlarged liver with an edge, and a palpable mass in the suprapubic area. Bilateral pitting oedema was present in both legs.

She was submitted to blood and urine tests, cervicoabdominal-pelvic magnetic resonance imaging (MRI) scan and echocardiogram (Table 1).

The results were compatible with a CS in association with elevated 24-hour urinary 5-hydroxyindoleacetic-acid (5-HIAA) secretion, and severe CHD. She was classified as stage 2-3 according to the New York Heart Association. The somatostatin analogue octreotide was initiated (50 $\mu \mathrm{g}$ TDS with progressive titration to $100 \mu \mathrm{g}$ TDS). A marked decrease in diarrhoea and flushing was observed, but the symptoms related to CHD remained. She was then submitted to tumour resection. The histology confirmed NET tumour, grade 1, in association with a teratoma (Fig.s 1 - 4). Post-operative serum chromogranins $A$ and $B$, urinary 5 HIAA (Table 1 ) and octreoscan were negative. The definitive resolution of $\mathrm{CHD}$ was achieved with bioprosthetic valve replacement of both tricuspid and pulmonary valves. She remains free of any cardiac disease, tumour recurrence or symptoms of the CS 3 years post-operatively.

\section{DISCUSSION}

Ovarian neuroendocrine tumours (ONET) are rare, accounting for $0.3 \%-1.0 \%$ of all NETs ${ }^{4}$ and $1 \%-2 \%$ of ovarian neoplasms. ${ }^{5}$ Primary ONET may be subdivided into four categories: insular, trabecular, mucinous, and strumal. ${ }^{6}$ The reported incidence of ONET-related CS depends on the histological type, ranging from $7.8 \%$ to $39 \%$, the insular type being the most frequently associated to this syndrome. ${ }^{7}$

NETs secrete vasoactive hormones, including $5-\mathrm{HT}$, tachykinins, kallikrein and prostaglandins. Generally, these are inactivated in the hepatic parenchyma by monoamine

Table 1 - Diagnostic exams performed for the assessment of carcinoid syndrome

\begin{tabular}{ll}
\hline Diagnostic exams & Results \\
\hline Blood and urine tests & Serum chromogranin A $2642 \mathrm{pmol} / \mathrm{L}(0-60)$ \\
(only abnormal results are shown) & Serum chromogranin B $313 \mathrm{pmol} / \mathrm{L}(0-150)$ \\
& 24-hour urine 5-HIAA $1700 \mathrm{mmol} / 24 \mathrm{~h}(10-40)$
\end{tabular}

Cervico-thoraco-abdominal MRI

Abnormal peripheral enhancement pattern within both lobes of the liver involving all segments. No definite hepatic metastases are present.

Hepatic veins and inferior vena cava appear distended. Small volume free fluid is present within the abdomen and pelvis. Early intrahepatic biliary dilatation; dilatation of the common bile duct. Extensive subcutaneous oedema throughout the abdominal and pelvic wall. Marked degree of bilateral hydronephrosis with ureteric dilation, with preservation of cortical thickness of both kidneys.

Large heterogeneous pelvic mass that appears inseparable from the uterus measuring $12 \mathrm{x}$ $10 \times 11 \mathrm{~cm}$. No nodal enlargement within the abdomen.

Small bibasal lamellar pleural effusions.

Echocardiogram

Tricuspid regurgitation with mild to moderate pulmonary valve stenosis and regurgitation.

The detailed cardiological features have been previously published. ${ }^{12}$

(5-HIAA): 5-hydroxyindoleacetic-acid; NR: Normal range; NA: Not available; * Only abnormal results are shown 


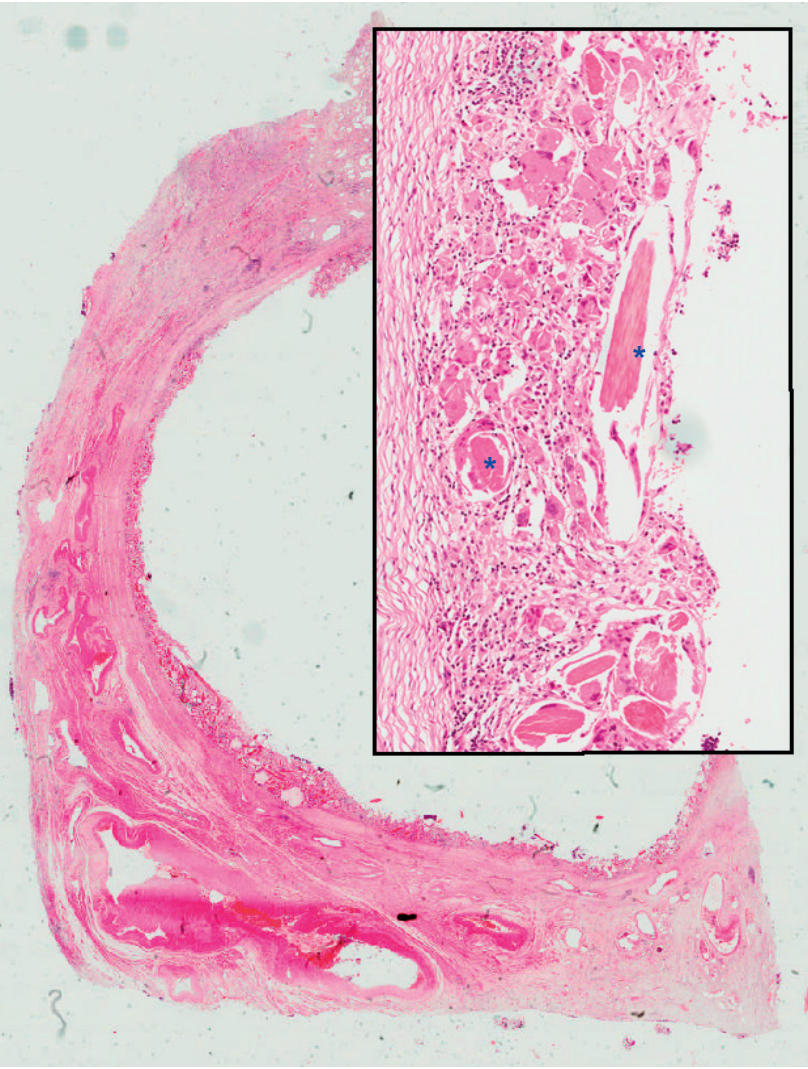

Figure 1 - Right ovary $(540 \mathrm{~g}, 11 \times 9 \times 7 \mathrm{~cm})$ with mature cystic monodermal teratoma component $(12.5 \mathrm{x})$ that is lined by florid giant cell reaction (inset, $200 \mathrm{x}$ ) to keratin material $\left(^{*}\right)$

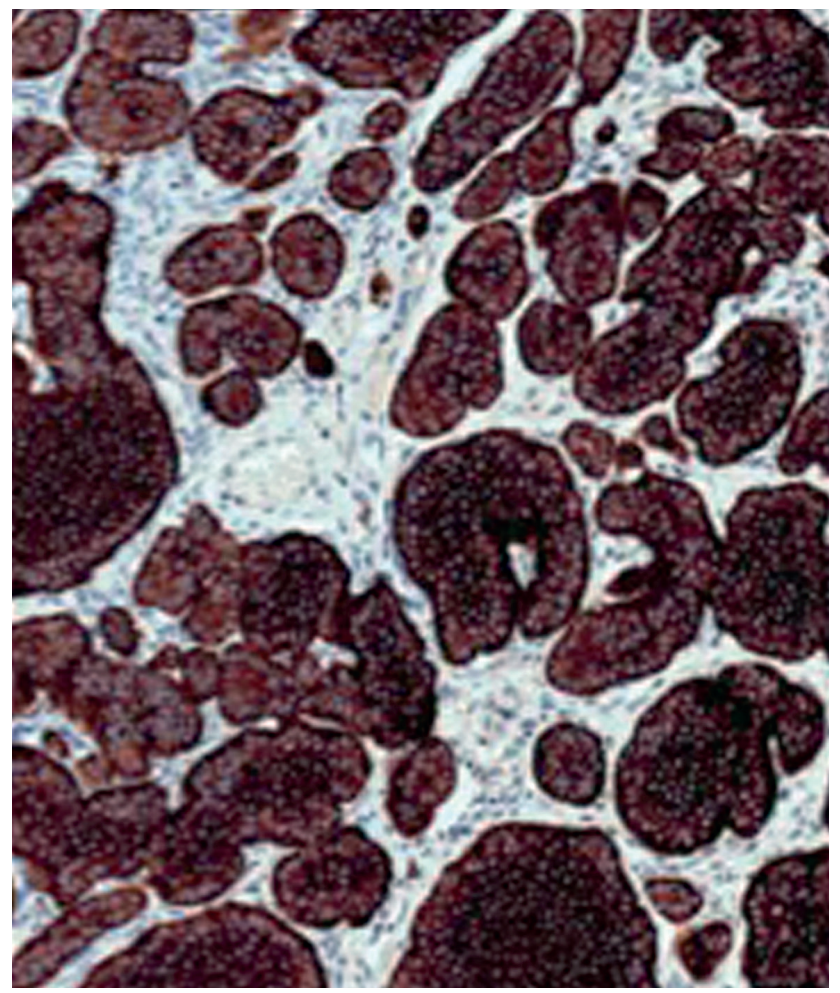

Figure 3 - Carcinoid component exhibiting positive expression with synaptophysin (inset, $200 \mathrm{x}$ ) immunohistochemistry

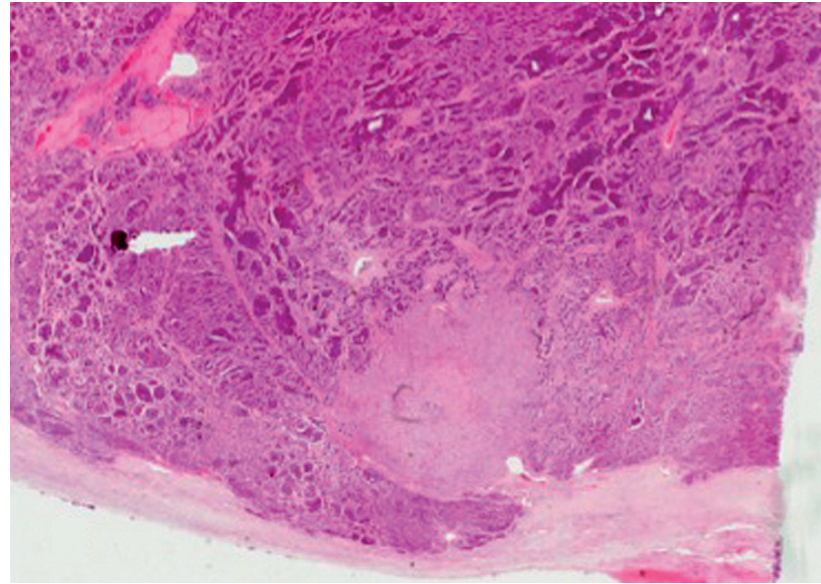

Figure 2 - Carcinoid component $(12.5 \mathrm{x})$ of the tumour

oxidases. However, when the liver's capacity is overwhelmed due to metastases, these hormones enter the systemic circulation, leading to the CS. Nevertheless, there are some cases in which the precondition of hepatic metastases is not required for the development of this disorder. In patients with ONET those hormones drain directly into the systemic circulation via the internal vena cava (right ovary) or renal vein (left ovary), by-passing the portal system, as well as in cases of extensive retroperitoneal lymph node metastases in whom the drainage by-passes the liver via thoracic duct and retroperitoneal venous collaterals. ${ }^{8,9}$ Patients with ONET can present symptoms and signs of right heart failure, including hepatomegaly, which is associated with decreased cardiac output, in the

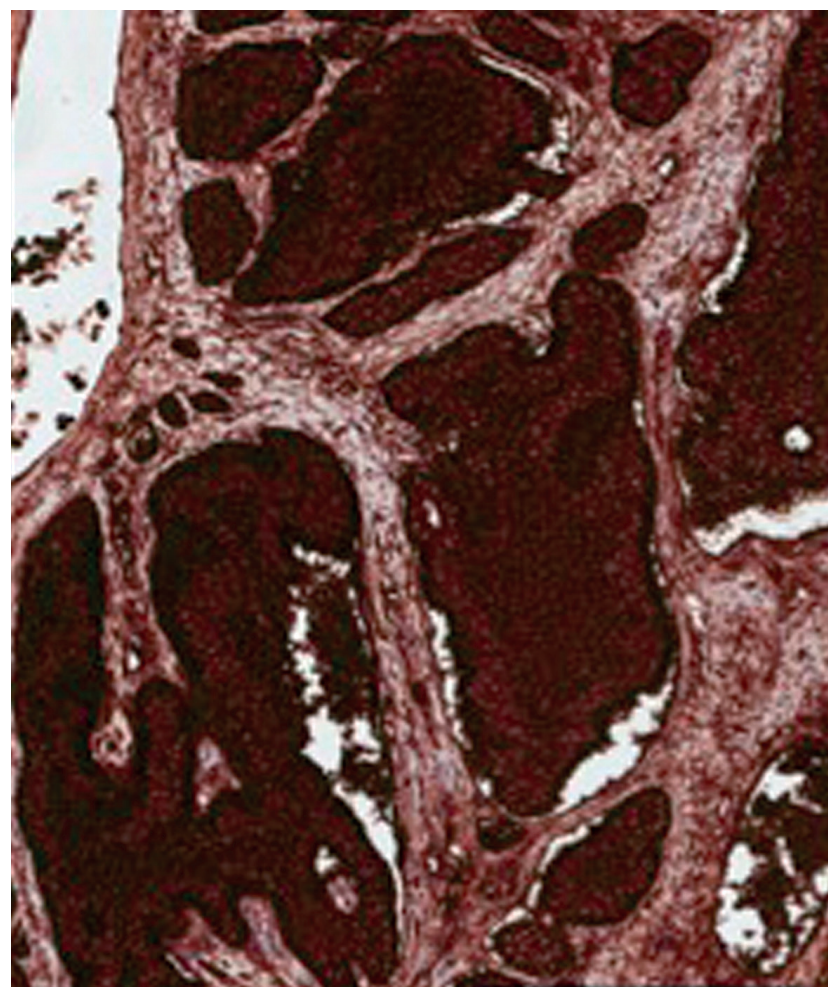

Figure 4 - Carcinoid component exhibiting positive expression with chromogranin (inset, $200 \mathrm{x}$ ) immunohistochemistry 
absence of metastases.

Carcinoid heart disease has been reported in up to $60 \%$ of patients with carcinoid syndrome. ${ }^{3} \mathrm{CHD}$ is typically rightsided, as the left side is usually spared due to inactivation of vasoactive hormones in the lungs, unless the tumour is situated in the lungs or there is a patent foramen ovale. ${ }^{10}$

Recently, Grozinsky-Glasberg et a/10 reported an extensive review on CHD highlighting its pathophysiology. This clinical entity is probably multifactorial and mediated by the different vasoactive hormones. Serotonin appears to play a key role in the development of CHD through receptors in the cardiac heart valves. ${ }^{11}$ Persistent overstimulation of these receptors increases the synthesis and upregulation of transforming growth factor- $\beta 1$ (TGF- $\beta 1$ ). This cytokine leads to the deposition of plaques in valve apparatus. CHD is strongly suggested on echocardiograms by the concomitant dysfunction of pulmonary and tricuspid valves. The deposition of plaques on the leaflets of pulmonary valve causes adhesion of pulmonic leaflets to the pulmonary arterial endocardium resulting in a mixture of valvular stenosis and regurgitation, whereas in the tricuspid valve the plaques involve mainly the subvalvular apparatus leading to regurgitation.

Treatment with somatostatin analogues and/or tumour debulking/resection may improve the CS as well as the negative haemodynamic impact of tumour hormones on CHD. ${ }^{10}$ However, somatostatin analogues cannot reverse established valvular dysfunction. ${ }^{12}$ Loop diuretics combined with fluid and salt restriction and compression stockings may initially relieve the symptoms if the CHD is mild, but may decrease the cardiac output in advanced cases. The definitive therapy of CHD can only be provided by valvular replacement. ${ }^{3}$ The choice between a mechanical or bioprosthetic valve should be an individualised decision. In selected cases, balloon valvoplasty of the right-sided valves was associated with symptomatic improvement in patients with stenotic tricuspid or pulmonary valves, although recurrent symptoms have been observed. Metastatic disease per se is not an absolute contraindication to surgery. ${ }^{3}$ The perioperative management should involve the use of intravenous infusion of octreotide to reduce the risk of intraoperative hypotension and carcinoid crisis. Antihistamines and corticosteroids may also be useful in the perioperative setting to control flushing and bronchospasm. ${ }^{10}$

This patient presented a past history of Roux-en-Y bypass due to obesity. Interestingly, some authors have been reporting the relationship between obesity or bariatric surgery and the development of certain neuroendocrine tumours. To our knowledge, the association between obesity or bariatric surgery and ONET has not been described. Keshishian et $a /^{14}$ observed a higher incidence of small intestine NETs in obese patients (1.5\%) compared to general population. Other authors have reported the presence of gastric $^{15}$ and duodenal ${ }^{16}$ NET in the preoperative setting. In fact, upper gastrointestinal endoscopy is recommended in the pre-bariatric surgery evaluation, ${ }^{17}$ rendering possible the NET diagnosis before the surgical procedure. Al-Harbi et $a^{18}$ believe that gastric NETs are probably related to abnormal feeding behavior of the obese patients. On the other hand, pancreatic NETs have been reported following bariatric surgery, ${ }^{19,20}$ usually diagnosed during hypoglycemic episodes' investigation. These authors described insulin producing tumours ${ }^{20}$ and co-secretion of GLP-1 and glucagon. ${ }^{19}$ This association may be coincidental, but the metabolic alterations, induced by weight loss and anatomical rearrangement of the gastrointestinal tract, may result in neuroendocrine alterations, like islet cell hyperplasia and expansion of the b-cell mass. ${ }^{19}$ Nevertheless, this association cannot be suspected in the particular case of our patient who developed an ovarian NET.

In summary, we present a case of an ovarian NET presenting with a CS and severe right-sided cardiac valvular dysfunction in whom there was no evidence of metastatic disease, and who has been cured of her symptoms by operative removal of the tumour and bivalvular replacement. These complex patients must be managed by an experienced multidisciplinary team including endocrinologists, oncologists, cardiologists, pathologists and cardiothoracic surgeons.

\section{OBSERVATIONS}

This work was presented as a poster at the Annual Meeting of the Portuguese Society of Endocrinology, Diabetes and Metabolism, 28-30/01/2016, Coimbra, Portugal, 2016.

\section{PROTECTION OF HUMANS AND ANIMALS}

The authors declare that the procedures were followed according to the regulations established by the Clinical Research and Ethics Committee and to the Helsinki Declaration of the World Medical Association.

\section{DATA CONFIDENTIALITY}

The authors declare having followed the protocols in use at their working center regarding patients' data publication.

\section{CONFLICT OF INTEREST}

The authors have no conflict of interest to declare.

\section{FUNDING SOURCES}

No subsidies or grants contributed to this work.

\section{REFERENCES}

1. Kvols LK. Metastatic carcinoid tumors and the malignant carcinoid syndrome. Ann NY Acad Sci. 1994;733:464-70.

2. Pellikka PA, Tajik AJ, Khandheria BK, Seward JB, Callahan JA, Pitot HC, et al. Carcinoid heart disease. Clinical and echocardiographic spectrum in 74 patients. Circulation. 1993;87:1188-96.
3. Fox DJ, Khattar RS. Carcinoid heart disease: presentation, diagnosis, and management. Heart. 2004;90:1224-28.

4. Maggard MA, O'Connell JB, Ko CY. Updated population-based review of carcinoid tumors. Ann Surg. 2004;240:117-22.

5. Diaz-Montes TP, Rosenthal LE, Bristow RE, Grumbine FC. Primary 
insular carcinoid of the ovary. Gynecol Oncol. 2004;101:175-8.

6. Zlerman A. Carcinoid tumors of the ovary. J Cancer Res Clin Oncol. 1984;107:125-35.

7. Soga J, Osaka M, Yakuwa Y. Carcinoids of the ovary: an analysis of 329 reported cases. J Exp Clin Cancer Res. 2000;19:271-80.

8. Morin LJ, Zuerner RT. Retroperitoneal fibrosis and carcinoid tumor. JAMA. 1971;216:1647-8.

9. Ansell JK, Stebbings WS. Carcinoid syndrome due to a primary ovarian carcinoid tumour. J R Soc Med. 1993;86:668.

10. Bhattacharrya S, Davar J, Dreyfus G. Carcinoid heart disease. Circulation. 2007;116:2860-5.

11. Grozinsky-Glasberg S, Grossman AB, Gross DJ. Carcinoid heart disease: from pathophysiology to treatment - 'something in the way it moves'. Neuroendocrinology. 2015;101:263-73.

12. Roy A, Brand NJ, Yacoub MH. Expression of 5-hydroxytryptamine receptor subtype messenger RNA in interstitial cells from human heart valves. J Heart Valve Dis. 2000;9:256-60.

13. Moller JE, Connolly HM, Rubin J, Seward JB, Modesto K, Pellikka PA Factors associated with progression of carcinoid heart disease. $\mathrm{N}$ Engl J Med. 2003;348:1005-15.

14. Melo P, Cahill TJ, Kardos A. A hot flush signals the way to a woman's heart. Int J Cardiol. 2014;171:e131-2.

15. Keshishian A, Hamilton J, Hwang L, Petrosyan M. Carcinoid tumor and bariatric surgery. Obes Surg. 2002;12:874-5.

16. Moretto M, Mottin CC, Padoin AV, Júnior SP, Barrios C. Gastric carcinoid tumor-incidental finding on endoscopy prior to bariatric surgery. Obes Surg. 2008;18:747-9.

17. Zeni TM, Frantzides CT, Mahr C, Denham EW, Meiselman M, Goldberg $\mathrm{MJ}$, et al. Value of preoperative upper endoscopy in patients undergoing laparoscopic gastric bypass. Obes Surg. 2006;16:142-6.

18. Tariq N, Chand B. Presurgical evaluation and postoperative care for the bariatric patient. Gastrointest Endosc Clin N Am. 2011;21:229-40.

19. Al-Harbi O, Shakir M, Al-Brahim N. Gastric carcinoid and obesity: association or coincidence? Report of two cases and literature review. Case Rep Gastrointest Med. 2013;2013:848075.

20. Zagury L, Moreira RO, Guedes EP, Coutinho WF, Appolinario JC Insulinoma misdiagnosed as dumping syndrome after bariatric surgery. Obes Surg. 2004;14:120-3.

21. Guimarães $M$, Rodrigues $P$, Pereira SS, Nora M, Gonçalves G, Albrechtsen NW, et al. GLP1 and glucagon co-secreting pancreatic neuroendocrine tumor presenting as hypoglycemia after gastric bypass. Endocrinol Diabetes Metab Case Rep. 2015;2015:150049. 